\title{
Soil Quality under Agroforestry Trees Pattern in Upper Citarum Watershed, Indonesia
}

\author{
Asep Mulyono 1,2*, Abraham Suriadikusumah', Rachmat Harriyanto', \\ Muhammad Rahman Djuwansah²
}

\author{
1 Soil Science and Land Resources Department, Faculty of Agriculture, Padjadjaran University, Sumedang, \\ 45363, West Java, Indonesia \\ 2 Research Center for Geotechnology, Indonesian Institute of Sciences, Bandung, 40135, West Java, Indonesia \\ * Corresponding author's e-mail: asepliwa@yahoo.co.id
}

\begin{abstract}
This paper discusses the setting up of a multivariate statistical method in selecting the useful soil quality indicators for soil quality assessment under agroforestry pattern. The of soil quality has been recognized as a tool to determine the sustainability of land resources, especially in agroforestry development. The study was carried out at Upper Citarum Watershed of Bandung district, West Java province, Indonesia. The soil samples were taken with purposive sampling under agroforestry pattern. Principal component analysis (PCA) was used as the multivariate statistical method to identify the minimum data set (MDS); scoring of each indicator, and data integration in the index of soil quality. The MDS consisted of four soil chemical indicators and represented $83.6 \%$ of the variability of data, i.e., pH, and exchangeable Calcium (exch Ca), organic Carbon (org C), and exchangeable Natrium (exch $\mathrm{Na}$ ) respectively. The soil quality index (SQI) was categorized under agroforestry pattern as moderate. The artificial agroforestry-based coffee with an intercropping system (timber woods, multi purpose trees and horticultures) provides better soil quality.
\end{abstract}

Keywords: soil quality, agroforestry, multivariate assessment, PCA, upper citarum watershed.

\section{INTRODUCTION}

The changes in land use has long been a problem around Upper Citarum watershed in Bandung district, Indonesia. Declining forest covers occurred due to the opening of forest lands for dry farming land and the proliferation of illegal logging (Chaidar et al., 2017). Land use conversions often negatively affect the functioning of soil (Emadi et al., 2009; Raiesi and Beheshti, 2014; Saviozzi et al., 2001; Spohn and Giani, 2011). The forests provide soil fertility, soil erosion protection and climate change mitigation (Aticho, 2013). Land conditions in the upper Citarum watershed, have been increasingly critical in recent times, causing various problems, especially the high erosion that is considered to be one of the factors causing river sedimentation and triggering flood disaster. A critical land area that occurred in the Upper Citarum watershed in 2013 reached 46,543 ha or $20.2 \%$ of total upstream area DAS, while in 2015 , it increased to $136,872.68$ ha or $59.3 \%$ of the entire area of an upstream watershed (Ministry of Agriculture, 2015).

Appropriate land management practices needed to reduce soil degradation and maintain better soil quality, decrease the critical land and increase land productivity. Agroforestry is a combination of forestry and agronomy to create harmony between the intensification of agriculture and forest conservation (King, 1979, 1976). Agroforestry constitutes the land use systems in which trees or shrubs are grown together with crops, pastures or livestock, and provide an ecological and economic interaction (Young, 1989).

The agroforestry system has been evolving under the influence of various biophysical and socioeconomic factors. Multiple forms of agro- 
forestry have long been known in the local land use systems (agroforest) in the Upper Citarum watershed. The locally known kebon tatangkalan is one of the most typical ones and has long been playing a significant role in the entire production system of the agricultural landscape (De Foresta and Michon, 1996; Michon and de Foresta, 1999; Parikesit et al., 2005). The agroforestry was used to increase the land productivity with multi purpose tree species, relay-cropping, terracing and contour cultivation, strip and alley cropping (Acharya and Kafle, 2009). The agroforestry system has the potential to reduce runoff and erosion, maintain better soil organic matter, which improves the fertility status of the soil (Nair, 1998). Agroforestry has the potential to maintain the land productivity, and soil fertility, adding to the economic contribution of farmer, also providing a positive impact on the conservation aspect (Hairiah et al., 2006; León and Osorio, 2014). The soil fertility under agroforestry was high compared to cropland (Kassa et al., 2017) and enhanced the content of natural degradable components in the organic matter (Marinho et al., 2014).

Agroforestry in the Upper Citarum watershed is currently declining from the landscape due to population growth and rapid regional economic development. Serious effort to revitalize this tra- ditional agroforest is needed to prevent its disappearance (Parikesit et al., 2005). However, the dense and critical land in the Upper Citarum watershed has been converted to agroforestry in the last decades. In order to build the agroforestry system in Upper Citarum watershed, evaluating the current condition of soil quality comprehensively becomes a necessity to determine the next conservation action.

Soil quality index (SQI) has been recognized as a tool for determining the sustainability of land resources (Karlen et al., 2003). Some researchers have evaluated and proposed various soil quality indicators that readily measured the changes of soil condition (Doran and Parkin, 1994; Karlen et al., 1998; Larson and Pierce, 1994). There are two methods of calculating the soil quality index that is Expert Judgment and Principal Components Analysis (Laishram et al., 2012). The multivariate statistical technique has widely been used for selecting effective soil quality indicators. The principal components analysis (PCA) method is a tool in data reduction to select some of the potential indicators (Qi et al., 2009). The objectives of this study were to find the soil quality indicators with a multivariate statistical method for soil quality assessment and to evaluate the soil quality index (SQI) under the agroforestry pattern.

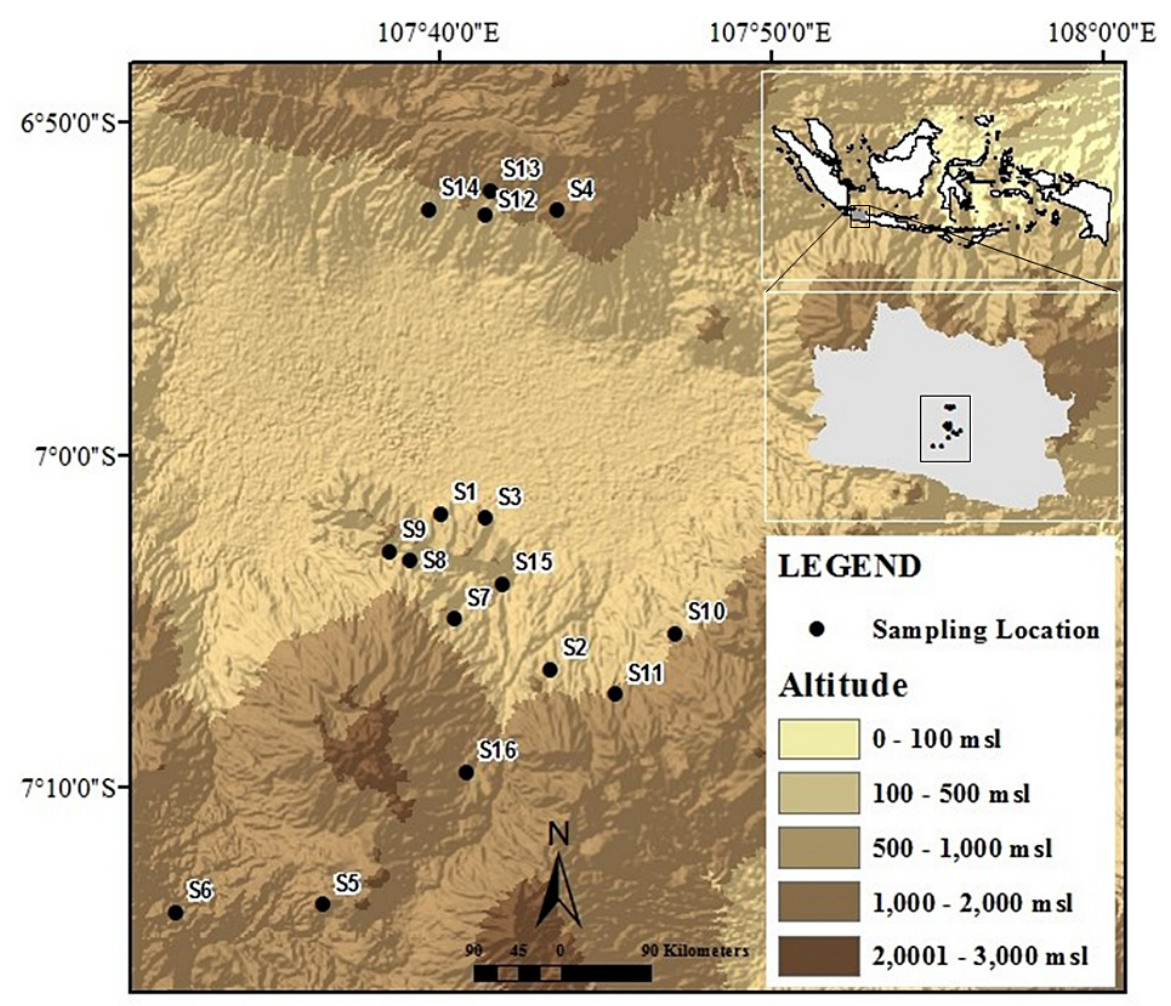

Figure 1. Index map showing the location of the collected sample 


\section{MATERIAL AND METHODS}

\section{Study area}

The study was carried out at Upper Citarum Watershed of Bandung district, West Java province, Indonesia (Figure 1). The average of annual precipitation is approximately in the range of $1.500-3.000 \mathrm{~mm}$.year ${ }^{-1}$. The study site was located in a tropical region, geographically located at $107^{\circ} 27^{\prime}$ to $107^{\circ} 49^{\prime}$ east longitude and $-7^{\circ} 16^{\prime}$ to $-6^{\circ} 48^{\prime}$ south longitude. Figure 1 shows the index map of the study area in which the sample was collected.

The geological conditions of the study area, are composed of volcanic rocks, sedimentary rocks, intrusion rocks, lake sediments and alluvium deposits (Alzwar et al., 1992; Silitonga, 1973). The geomorphology of Bandung district is divided into flat and hills zones. The flat zone is located in the northern part of Bandung district with elevation ranging from 500 to 1000 mean sea level (msl) and composed of sedimentary volcanoes in Quarter age. The hilly zone is located in the southern part of the study area with the el- evation ranging from $1000-2500 \mathrm{msl}$; it is composed of rocks with volcanic genesis. The major soil unit is separated into Inceptisol and Andisols (Soil and Agroclimate Research Center, 1993; Soil Survey Staff, 2014).

\section{Method}

This study was conducted from May to July 2017. Geo-referenced surface soil samples and tools were used in the field analysis consisting of soil auger, clinometer, $\mathrm{pH}$ stick, distilled water, and other chemicals for soil judgment. The soil samples collected with purposive sampling from $0-30 \mathrm{~cm}$ depth were obtained from the agroforestry pattern (Table 1) based on Combe and Budowski (1979).

The samples were taken, and air-dried at room temperature for physical and chemical properties. The soil chemical analyses carried out involved determining: the soil $\mathrm{pH}$ in 1:2.5 soilwater suspension, measured using a $\mathrm{pH}$-meter, cation exchange capacity (CEC) with the ammonium acetate method (Hesse and Hesse, 1971), organic carbon (Walky and Black, 1934), total

Table 1. Soil sampling description

\begin{tabular}{|c|c|c|c|c|}
\hline \multirow{2}{*}{ Soil location } & \multicolumn{2}{|l|}{ Agroforestry pattern } & \multirow{2}{*}{ Slope (\%) } & \multirow{2}{*}{ Soil Type } \\
\hline & Composed & Cropping & & \\
\hline S1 & Mangifera indica L, Musa paradisiaca L, Bambuseae & Random & $3-8$ & Andisols \\
\hline S2 & $\begin{array}{l}\text { Albizia chinensis, Musa paradisiaca L, Manihot } \\
\text { esculenta }\end{array}$ & Random & $8-15$ & Inceptisols \\
\hline S3 & $\begin{array}{l}\text { Persea americana Mill, Toona sureni Merr, Musa } \\
\text { paradisiaca L, Manihot esculenta }\end{array}$ & Random & $15-30$ & Andisols \\
\hline S4 & $\begin{array}{l}\text { Coffea arabica L, Artocarpus heterophyllus Lam, } \\
\text { Gmelina arborea }\end{array}$ & Alley cropping & $15-30$ & Andisols \\
\hline S5 & $\begin{array}{l}\text { Coffea arabica L, Artocarpus heterophyllus Lam, } \\
\text { Mangifera indica L, Musa paradisiaca L }\end{array}$ & Alley cropping & $3-8$ & Andisols \\
\hline S6 & $\begin{array}{l}\text { Coffea arabica L, Brassica rapa L, Solanum } \\
\text { lycopersicum }\end{array}$ & Alley cropping & $15-30$ & Andisols \\
\hline S7 & Tectona grandis, Allium fistulosum & Alley cropping & $8-15$ & Andisols \\
\hline S8 & Gmelina arborea, Manihot esculenta & Alley cropping & $8-15$ & Andisols \\
\hline S9 & Gmelina arborea, Zingiber officinale, Carica papaya & Random & $30-45$ & Andisols \\
\hline S10 & $\begin{array}{l}\text { Albizia chinensis, Mangifera indica L, Manihot } \\
\text { esculenta }\end{array}$ & Random & $3-8$ & Inceptisols \\
\hline S11 & $\begin{array}{l}\text { Tectona grandis, Albizia chinensis, Synedrella } \\
\text { nudiflora }\end{array}$ & Random & $30-45$ & Inceptisols \\
\hline S12 & $\begin{array}{l}\text { Syzygium aromaticum, Manihot esculenta, } \\
\text { Synedrella nudiflora }\end{array}$ & Alley cropping & $8-15$ & Inceptisols \\
\hline S13 & $\begin{array}{l}\text { Syzygium aromaticum, Manihot esculenta, Mangifera } \\
\text { indica L, Gnetum gnemon, Durio sp }\end{array}$ & Random & $30-45$ & Inceptisols \\
\hline S14 & $\begin{array}{l}\text { Mangifera indica L, Musa paradisiaca L, Ageratum } \\
\text { conyzoides }\end{array}$ & Random & $3-8$ & Inceptisols \\
\hline S15 & $\begin{array}{l}\text { Albizia chinensis, Manihot esculenta, Ageratum } \\
\text { conyzoides }\end{array}$ & Random & $3-8$ & Inceptisols \\
\hline S16 & $\begin{array}{l}\text { Toona sureni Merr, Musa paradisiaca L, Synedrella } \\
\text { nudiflora }\end{array}$ & Random & $30-45$ & Inceptisols \\
\hline
\end{tabular}


nitrogen using the Kjeldahl method (Bremner et al., 1996), available phosphorus (Olsen, 1954), available-K using a flamephotometer method, exchangeable potassium $(\mathrm{K})$, sodium $(\mathrm{Na})$, calcium $(\mathrm{Ca})$, magnesium $(\mathrm{Mg})$ by means of the ammonium acetate $\left(1 \mathrm{M} \mathrm{NH}_{4} \mathrm{OAc}\right.$ at $\left.\mathrm{pH} 7\right)$ extraction method. Soil chemical categorizing was based on the soil chemical standard (Indonesian Soil Research Institute, 2005).

All statistical analysis were performed by means of PAST v.3.18 software (Hammer et al., 2001). In order to synthesize all of the selected parameters, a soil quality index (SQI) was assessed by scoring of chosen variables. Determination of the weight of each determinant of soil quality, SQI was calculated using the formula (Andrews et al., 2004; Qi et al., 2009) with the following equation :

$$
S Q I=\sum_{i=1}^{n}\left(W_{i}+S_{i}\right)
$$

where $W_{i}=$ the assigned a weight of each indicator, which is gained from a selected principal component,

$S_{i}=$ the score of the indicator,

$n=$ the number of variables in the refined minimum data set (MDS).

SQI classification was used to determine soil quality status in the study site (Cantú et al., 2007). The high score of SQI indicates that the soil has high quality (Table 2).

\section{RESULT AND DISCUSSION}

\section{Soil Attributes}

The soil in the study area is composed by $3-31 \%$ of sand particles, $12-68 \%$ of silt particles and $27-83 \%$ of clay particles. The soil texture in the study area was $69 \%$ clay (S1, S2, S3, S5, S6, S7, S8, S9, S10, S15, and S16), 25\% silty clay

Table 2. Soil quality index (SQI) classification

\begin{tabular}{|c|l|c|}
\hline No & SQI Classification & SQI Score \\
\hline 1 & Very good & $0.80-1.00$ \\
\hline 2 & Good & $0.60-0.79$ \\
\hline 3 & Moderate & $0.35-0.59$ \\
\hline 4 & Low & $0.20-0.34$ \\
\hline 5 & Very low & $0.00-0.19$ \\
\hline
\end{tabular}

loam (S11, S12, S13, S14), and 6\% clay loam (S4). The categorized soil $\mathrm{pH}$ was acidic $(<5.5)$ and slightly acidic (5.5-6.5) for all location. The ocation $\mathrm{S} 7$ had the lowest value of $\mathrm{pH}$ and the maximum $\mathrm{pH}$ showed in location $\mathrm{S} 1$. Total nitrogen considered as low to moderate, with the lowest concentration in the location S3 and the maximum showed in the location S4. Organic carbon (org C) was low $(2-3 \%)$ in the locations S1, S3, $\mathrm{S} 5, \mathrm{~S} 7, \mathrm{~S} 12$, and S16, moderate $(2-3 \%)$ in the locations S2, S6, S9, S14, and S15 and high (2-3\%) in the locations $\mathrm{S} 4, \mathrm{~S} 8$, and $\mathrm{S} 13$.

The available phosphorus (Av-P) was high (41-60 ppm) in the locations S2, S3, S8, and S12 and very high $(>60 \mathrm{ppm})$ in the rest. The available potassium (av-K) was low (10-20 ppm) in the locations S2, S3, S7, S11, and S13, moderate (>20-40 ppm) in the locations S14, high (40-60 ppm) in the locations S4, S5, S6, and $\mathrm{S} 13$ and very high $(>60 \mathrm{ppm})$ in the rest. The exchangeable magnesium (exch $\mathrm{Mg}$ ) in all locations was high $\left(>8 \mathrm{cmol} \cdot \mathrm{kg}^{-1}\right)$. The exchangeable calcium (exch Ca) was moderate $\left(6-10 \mathrm{cmol} \cdot \mathrm{kg}^{-1}\right)$ in the locations S1, S2, S8, S9, S11, S15, and S16 and high $\left(>10-20 \mathrm{cmol}^{\left.-\mathrm{kg}^{-1}\right)}\right.$ in the rest.

The exchangeable potassium (exch $\mathrm{K}$ ) was low $\left(0.1-0.3 \mathrm{cmol} . \mathrm{kg}^{-1}\right)$ in the locations $\mathrm{S} 2, \mathrm{~S} 3$, $\mathrm{S} 7, \mathrm{~S} 8, \mathrm{~S} 10$, and S14, moderate $(>0.3-0.5 \mathrm{cmol}$. $\mathrm{kg}^{-1}$ ) in the locations $\mathrm{S} 1, \mathrm{~S} 9$, and S15 and high $\left(>0.6-1.0 \mathrm{cmol}^{\left.-\mathrm{kg}^{-1}\right)}\right.$ in the locations S6, S11, $\mathrm{S} 12, \mathrm{~S} 13$, and S16, very high $\left(>1.0 \mathrm{cmol} . \mathrm{kg}^{-1}\right)$ in the rest. Base saturation (BS) in all locations was very high $(>80 \%)$ and cation exchange capacity (CEC) was considered as very low $\left(<5 \mathrm{cmol} . \mathrm{kg}^{-1}\right)$ in the locations S2 and S16, low (5-16 cmol. $\left.\mathrm{kg}^{-1}\right)$ in the locations $\mathrm{S} 1$, moderate $\left(>16-25 \mathrm{cmol} \cdot \mathrm{kg}^{-1}\right)$ in the locations S2, S5, S6, S8, S9, S11, S13, and $\mathrm{S} 15$, high $\left(>25-40 \mathrm{cmol}^{\mathrm{kg}}{ }^{-1}\right)$ in the locations S3, S7, S10, and S14.

The statistical methods were applied regarding the correlation and classification among the selected soil. The basic statistical analysis was used to determine minimum, mean, maximum, standard deviation, a coefficient of variation (CV), and skewness (Table 3). The coefficient of variation $(\mathrm{CV})$ is classified as weak variability if $\mathrm{CV}<10 \%$, moderate variability if $\mathrm{CV}$ ranged $10-100 \%$ and strong variability if $\mathrm{CV}>100 \%$ (Jin et al., 2015). In this study, CV ranged from $10-100 \%$, which is classified as weak to moderate variability. Table 3 shows the soil chemical statistical results. The $\mathrm{pH}$ was classified as weak variability with $\mathrm{CV}<10 \%$ and other variables 
Table 3. Soil chemical statistical analysis results.

\begin{tabular}{|l|c|c|c|c|c|c|}
\hline \multicolumn{1}{|c|}{ Parameters } & Min & Max & Mean & SD & Skewness & CV \\
\hline $\mathrm{pH}$ & 4.70 & 6.30 & 5.54 & 0.39 & -0.64 & 7.13 \\
\hline org C & 1.07 & 3.26 & 2.32 & 0.64 & -0.25 & 27.49 \\
\hline total N & 0.14 & 0.40 & 0.23 & 0.07 & 0.87 & 31.54 \\
\hline CN ratio & 8.00 & 17.00 & 10.19 & 2.26 & 1.84 & 22.16 \\
\hline av P & 41.65 & 324.20 & 141.53 & 82.17 & 0.61 & 58.06 \\
\hline av K & 8.31 & 52.16 & 22.41 & 15.82 & 0.83 & 70.58 \\
\hline exch Ca & 6.05 & 17.99 & 10.93 & 3.98 & 0.02 & 36.40 \\
\hline exch Mg & 2.33 & 6.72 & 3.36 & 1.12 & 2.04 & 33.32 \\
\hline exch K & 0.12 & 1.29 & 0.52 & 0.38 & 0.61 & 72.75 \\
\hline exch Na & 0.05 & 0.79 & 0.38 & 0.22 & 0.33 & 59.31 \\
\hline CEC & 15.98 & 36.29 & 23.35 & 5.73 & 0.69 & 24.55 \\
\hline BS & 50.00 & 83.00 & 64.19 & 9.62 & 0.34 & 14.99 \\
\hline
\end{tabular}

$\mathrm{SD}$ - standard deviation, $\mathrm{CV}$ - coefficient of variation, org $\mathrm{C}$ - organic carbon, av $\mathrm{P}$ - available phosphorus, av $\mathrm{K}$ - available potassium, exch $\mathrm{Ca}$ - exchangeable calcium, exch $\mathrm{Mg}$ - exchangeable magnesium, exch $\mathrm{K}$ - exchangeable potassium, exch $\mathrm{Na}$ - exchangeable natrium, $\mathrm{CEC}$ - cation exchange capacity, $\mathrm{BS}$ - base saturation.

were classified as moderate variability with $\mathrm{CV}$ ranging within $10-100 \%$.

The $\mathrm{pH}$ and org $\mathrm{C}$ have smaller mean values instead of their median values, corresponding with their negative skewness. Furthermore, all indicators except $\mathrm{pH}$ and org $\mathrm{C}$, have greater mean values instead of their median values, corresponding with their positive skewness. The av $\mathrm{K}$ and exch $\mathrm{K}$ exhibit larger variation than other indicators due to their higher $\mathrm{CV}$ values. The maximum values of av $\mathrm{K}$ and exch $\mathrm{K}$ were found in soil with agroforestry composed by Artocarpus heterophyllus Lam, Coffea arabica L, Mangifera indica $L$, Musa paradisiaca $L$ with slope ranged 3-8\% (S5). Furthermore, the minimum $\mathrm{CV}$ values represented by $\mathrm{pH}$ were observed in S7 by mixed food crops (Allium fistulosum) and wood crops (Tectona grandis).

\section{The relationship between soil chemical variables}

Pearson correlation analysis results of soil chemical data are performed with the confidence leve1 $95 \%$ and $99 \%$, to determine the relationship between variables (Li et al., 2013) as described in Table 4. Among the total concentration results, several variables have a positive correlation with others. On the other hand, several variables have negative correlation, which indicates that the indicators negatively affect each other. In Table 4, there were positive correlations at significant levels $<0.01$ among variables, i.e. total $\mathrm{N}-\operatorname{org} \mathrm{C}(0.785)$, Av-P-total N (0.626), Av KAv-P (0.803), exch Mg-exch Ca (0.623), exch
$\mathrm{K}-\mathrm{av} \quad \mathrm{K}$ (0.600), CEC-exch Ca (0.902), CEC-exch Mg (0.757), and BS-exch Ca (0.729). Furthermore, positive correlations at significant levels $<0.05$ among variables, i.e. total exch $\mathrm{K}-\mathrm{av} \mathrm{P}(0.600)$, exch Ca-total N (0.622), exch $\mathrm{Na}-$ exch $\mathrm{Ca}(0.568)$, and CEC-exch Na (0.537). The highest correlation was between CEC-av Ca $(0.902$ at significant levels $<0.01)$ and the lowest correlation showed between CEC av Na (0.537) at significant levels $<0.05$.

\section{PCA, MDS, and SQI clustering}

The relationship between the eigenvalue and principal components (PCs) is shown in Figure 2, with an increase in $\mathrm{PC}$, there is a corresponding decrease in the eigenvalue. In Figure 2, the increase in PCs up to 4, there was a steep decline in eigenvalue. However, after the increase in PC from 4 to 12 , there was a gradual decline in the eigenvalue.

The PCs with the eigenvalue $>1$ were selected for interpretation, and the PCs receiving high eigenvalue and variable with a high weight or factor loading were considered to best represent the soil indicators (Andrews et al., 2004; Brejda et al., 2000). The PCs which were eligible as data set included PC1 to PC4 (eigen value $\geq 1$ ), and represented $83.6 \%$ of the data variability (Table 5). PC1 with an eigenvalue of 4.365 , explained about $36.4 \%$ of the variance (Table 5). The $\mathrm{pH}$ with positive factor loading (0.256), org $\mathrm{C}(0.300)$, total $\mathrm{N}(0.622)$, av $\mathrm{P}$ (0.766), av K (0.748), exch Ca (0.825), exch $\mathrm{Mg}$ (0.159), exch K (0.531), exch Na (0.714), 
Table 4. Pearson correlation analysis results.

\begin{tabular}{|c|c|c|c|c|c|c|c|c|c|c|c|c|}
\hline Parameters & $\mathrm{pH}$ & $\operatorname{org} \mathrm{C}$ & total $\mathrm{N}$ & $\mathrm{CN}$ ratio & av $\mathrm{P}$ & av K & exch $\mathrm{Ca}$ & exch Mg & exch $\mathrm{K}$ & exch $\mathrm{Na}$ & CEC & BS \\
\hline $\mathrm{pH}$ & 1 & & & & & & & & & & & \\
\hline org $C$ & 0.03 & 1 & & & & & & & & & & \\
\hline total $\mathrm{N}$ & 0.063 & $.785^{* *}$ & 1 & & & & & & & & & \\
\hline $\mathrm{CN}$ ratio & -0.09 & 0.281 & -0.345 & 1 & & & & & & & & \\
\hline av $P$ & 0.063 & 0.487 & $.626^{* *}$ & -0.182 & 1 & & & & & & & \\
\hline av K & 0.222 & 0.287 & 0.373 & -0.188 & $.803^{* *}$ & 1 & & & & & & \\
\hline exch Ca & 0.13 & -0.09 & 0.221 & -0.481 & 0.425 & 0.461 & 1 & & & & & \\
\hline exch Mg & 0.139 & -0.475 & -0.347 & -0.238 & -0.34 & -0.162 & $.623^{* *}$ & 1 & & & & \\
\hline $\operatorname{exch} \mathrm{K}$ & 0.178 & 0.175 & 0.302 & -0.241 & $.600^{*}$ & $.673^{* *}$ & 0.212 & -0.391 & 1 & & & \\
\hline exch $\mathrm{Na}$ & 0.139 & 0.434 & $.622^{*}$ & -0.335 & 0.431 & 0.328 & $.568^{*}$ & 0.154 & 0.001 & 1 & & \\
\hline CEC & 0.003 & -0.042 & 0.193 & -0.396 & 0.256 & 0.286 & $.902^{* *}$ & $.757^{* *}$ & -0.052 & $.537^{*}$ & 1 & \\
\hline BS & 0.348 & -0.222 & 0.061 & -0.425 & 0.347 & 0.427 & $.729^{* *}$ & 0.29 & 0.485 & 0.37 & 0.383 & 1 \\
\hline
\end{tabular}

SCP - soil chemical properties, org $\mathrm{C}$ - organic carbon, av $\mathrm{P}$ - available phosphorus, av $\mathrm{K}$ - available potassium, exch $\mathrm{Ca}$ - exchangeable calcium, exch $\mathrm{Mg}$ - exchangeable magnesium, exch $\mathrm{K}$ - exchangeable potassium, exch $\mathrm{Na}$ - exchangeable natrium, $\mathrm{CEC}$ - cation exchange capacity, $\mathrm{BS}$ - base saturation, $* *$ correlation is significant at the 0.01 level (2-tailed), * correlation is significant at the 0.05 level (2-tailed)

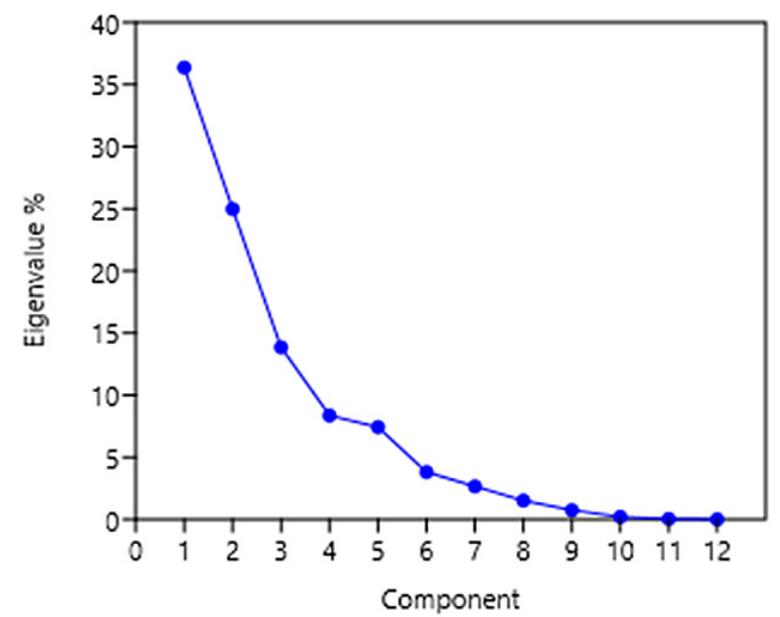

Figure 2. The relationship between eigen value and principal component

CEC (0.656), and BS (0.681). PC2 included org $\mathrm{C}$ with positive factor loading $(0.741)$, total $\mathrm{N}$ (0.538), CN ratio (0.314), av $\mathrm{P}(0.478)$, av $\mathrm{K}$ (0.302), and exch K (0.410)

PC2 explained about $25 \%$ of variance and eigenvalue of 2.997. Organic $\mathrm{C}$ with positive factor loading (0.495), total $\mathrm{N}(0.425), \mathrm{CN}$ ratio (0.097), exch Ca (0.050), exch Mg (0.180), exch $\mathrm{Na}(0.512)$, and CEC (0.345), was included in PC3 and explained $13.9 \%$ of the variance with eigenvalue of 1.662. PC4 included the $\mathrm{pH}$ with positive factor loading (0.880), org C (0.205), total N (0.020), CN ratio (0.247), exch Na (0.176), and BS (0.106), with negative factor loading in av $\mathrm{P}$, av $\mathrm{K}$, exch $\mathrm{Ca}$, exch $\mathrm{K}$, and $\mathrm{CEC}$, respectively. PC4 explained about $8.4 \%$ of the variance and eigenvalue of 1.003 .
There are three steps in the elaboration of a quality index (Karlen et al., 2003), i.e., a definition of minimum data set (MDS), scoring of each indicator by mathematical functions, and data integration in the index. The parameters obtained for each variable or indicator were analyzed in the principal component analysis (PCA) to identify the MDS. The principal component (PCs) which has an eigenvalue equal or higher than 1 was taken as MDS. One indicator with the highest value and taken as weighting index (Wi) was chosen in every selected PC.

The first principle component (PC1), a highly weighted attribute included (total $\mathrm{N}$, av $\mathrm{P}$, av K, exch $\mathrm{Ca}$, exch $\mathrm{Na}, \mathrm{CEC}$, and $\mathrm{BS}$ ) were significantly $(p<0.01)$ correlated with each other. The highest factor loading in $\mathrm{PC} 1$ are exch $\mathrm{Ca}$ was chosen for the MDS (Table 5). In PC2, org C showed higher factor loading, while in PC3, and PC4 - exch $\mathrm{Na}$ and $\mathrm{pH}$. Therefore, the final variable chosen for MDS included the following indicators; $\mathrm{pH}$, org $\mathrm{C}$, exch $\mathrm{Ca}$ and exch $\mathrm{Na}$. Hence, the weighting factors $\left(\mathrm{W}_{\mathrm{i}}\right)$ for the variable in PC1 (exch Ca), PC2 (org C), $\mathrm{PC} 3$ (exch Na) and PC4 (pH), are 0.825, 0.741, 0.512 , and 0.825 .

The soil quality index calculated from the indicators was chosen for MDS ( $\mathrm{pH}$, org $\mathrm{C}$, exch $\mathrm{Ca}$ and exch $\mathrm{Na}$ ). This variables were identified as indicators of soil quality. Each indicator was assigned scores, based on the weighting coefficient factors for MDS variable determined with the PCA result. Quantifying the soil quality requires a minimum data set (Schloter et al., 2006), and combining minimum data set variables in a meaningful way into a single index may enhance the assess- 
Table 5. PCA for MDS determination

\begin{tabular}{|l|c|c|c|c|}
\hline \multicolumn{1}{|c|}{ Statistical parameters } & PC1 & PC2 & PC3 & PC4 \\
\hline Eigen value & 4.365 & 2.997 & 1.662 & 1.003 \\
\hline \% variance & 36.371 & 24.976 & 13.851 & 8.362 \\
\hline Cumulative variance (\%) & 36.371 & 61.347 & 75.198 & 83.560 \\
\hline \multicolumn{4}{|c|}{ Soil chemical properties } \\
\hline pH & 0.259 & -0.058 & -0.315 & 0.880 \\
\hline org C & 0.300 & 0.741 & 0.495 & 0.205 \\
\hline total N & 0.622 & 0.538 & 0.425 & 0.020 \\
\hline CN ratio & -0.531 & 0.314 & 0.097 & 0.247 \\
\hline av P & 0.766 & 0.478 & -0.080 & -0.162 \\
\hline av K & 0.748 & 0.302 & -0.318 & -0.055 \\
\hline exch Ca & 0.825 & -0.514 & 0.050 & -0.081 \\
\hline exch Mg & 0.159 & -0.926 & 0.180 & 0.115 \\
\hline exch K & 0.531 & 0.410 & -0.636 & -0.147 \\
\hline exch Na & 0.714 & -0.010 & 0.512 & 0.176 \\
\hline CEC & 0.656 & -0.581 & 0.345 & -0.116 \\
\hline BS & 0.681 & -0.331 & -0.448 & 0.106 \\
\hline
\end{tabular}

$\mathrm{PC}$ - Principal component, org $\mathrm{C}$ - organic carbon, av $\mathrm{P}$ - available phosphorus, av $\mathrm{K}$ - available potassium, exch $\mathrm{Ca}$ - exchangeable calcium, exch $\mathrm{Mg}$ - exchangeable magnesium, exch $\mathrm{K}$ - exchangeable potassium, exch $\mathrm{Na}-$ exchangeable natrium, $\mathrm{CEC}$ - cation exchange capacity, $\mathrm{BS}$ - base saturation

ment (Andrews et al., 2004). The minimum data set (MDS) for selecting and representing the total dataset (Doran and Parkin, 1994; Karlen et al., 1998) can save time and money (Govaerts, et al., 2006). Principal component analysis (PCA) for selecting minimum data set (MDS) was used to evaluate agricultural soil quality in Zhangjiagang, China (Qi et al., 2009) and was applied in soil quality assessment of wheat and maize cropping in the highlands of Mexico (Govaerts, et al., 2006).

In this study, four indicators were selected from twelve as soil quality indicators i.e., $\mathrm{pH}$ and exch $\mathrm{Ca}$, org $\mathrm{C}$, and exch $\mathrm{Na}$ (Table 5). The properties in soil quality rating (Doran and Parkin, 1994) resulted from soil organic carbon, soil $\mathrm{pH}$, nitrogen $(\mathrm{N})$, exchangeable phosphorus and exchangeable potassium as soil chemical indicators. Ten soil properties, as MDS $(\mathrm{pH}$, electric conductivity, NO3-N, available phosphorus, soil organic carbon, microbial biomass carbon, $\mathrm{Cd}, \mathrm{Hg}, \mathrm{HCHs}$ and DDTs) were used to evaluate soil quality index under different planting patterns and soil types (Bi et al., 2013). Soil organic carbon was selected as the most dominant soil attribute in soil quality assessment (Shukla et al., 2006). Organic- $\mathrm{C}, \mathrm{pH}$, available $\mathrm{P}$ and available $\mathrm{K}$ constituted the minimum data set in soil quality assessment on tobacco plant in Sindoro mountainous zone (Supriyadi et al., 2017).

The scores of SQI in all locations were indicated in Table 6 . The comparison of these rates with soil quality classes (Cantú et al., 2007) showed that the soil quality in agroforestry pattern was established as low (0.20-0.34) and moderate (0.35-0.59).

The SQI obtained through soil location in the agroforestry pattern varied within $0.3-0.58$ (Table 6). The lowest SQI (0.3) at location S16 in slope condition ranged between $30-45 \%$-this is the location of agroforestry with vegetation arranged by Toona Sureni Merr, Musa paradisiaca L, Synedrella nudiflora with random cropping pattern. The location of S13 is a natural agroforestry site consisting of mixed fruit and food crops (Syzygium aromaticum, Manihot esculenta, Mangifera indica L, Gnetum gnemon, Durio $s p$ ) which has the highest SQI (0.58).

Cluster analysis is used to assemble objects based on the soil chemicals characteristics. In this process, hierarchical clustering joins the most similar observations in the dendrogram. The dendrogram of the 16 soil samples is shown in Figure 3.

There are three cluster groups in the dendrogram, in which cluster 1 group possess $56 \%$ of total samples, cluster 2 has $25 \%$ samples, and cluster 3 has $19 \%$ soil samples. Table 7 shows the cluster group, sample location concerning cluster group, percentage of sample belongs to each cluster group and soil quality index group.

The similarity of grouped soil samples, their grouped min., max., and mean value of chemical parameters showed in Table 8. Cluster 1 group has 
Table 6. SQI classification of each study location

\begin{tabular}{|c|c|c|c|c|c|c|}
\hline \multirow{5}{*}{ Soil location } & \multicolumn{4}{|c|}{ MDS } & \multicolumn{2}{|c|}{ SQI } \\
\hline & $\mathrm{pH}$ & org C & exch $\mathrm{Ca}$ & exch $\mathrm{Na}$ & \multirow{4}{*}{ Score } & \multirow{4}{*}{ Classification } \\
\hline & \multicolumn{4}{|c|}{ PCA (Wi) } & & \\
\hline & 0.880 & 0.741 & 0.825 & 0.512 & & \\
\hline & \multicolumn{4}{|c|}{ Si } & & \\
\hline S1 & 0.909 & 0.552 & 0.318 & 0.334 & 0.41 & Moderate \\
\hline S2 & 0.808 & 0.577 & 0.312 & 0.058 & 0.36 & Moderate \\
\hline S3 & 0.837 & 0.298 & 0.909 & 0.265 & 0.46 & Moderate \\
\hline S4 & 0.808 & 0.890 & 0.761 & 0.587 & 0.57 & Moderate \\
\hline S5 & 0.837 & 0.502 & 0.701 & 0.334 & 0.46 & Moderate \\
\hline S6 & 0.823 & 0.714 & 0.638 & 0.403 & 0.50 & Moderate \\
\hline S7 & 0.678 & 0.538 & 0.625 & 0.449 & 0.44 & Moderate \\
\hline S8 & 0.779 & 0.848 & 0.316 & 0.334 & 0.44 & Moderate \\
\hline s9 & 0.778 & 0.756 & 0.405 & 0.230 & 0.42 & Moderate \\
\hline S10 & 0.749 & 0.759 & 0.638 & 0.806 & 0.54 & Moderate \\
\hline S11 & 0.802 & 0.678 & 0.319 & 0.150 & 0.39 & Moderate \\
\hline $\mathrm{S} 12$ & 0.810 & 0.496 & 0.649 & 0.575 & 0.48 & Moderate \\
\hline S13 & 0.798 & 0.909 & 0.724 & 0.702 & 0.58 & Moderate \\
\hline S14 & 0.846 & 0.625 & 0.756 & 0.909 & 0.57 & Moderate \\
\hline S15 & 0.837 & 0.811 & 0.463 & 0.690 & 0.52 & Moderate \\
\hline S16 & 0.693 & 0.404 & 0.306 & 0.092 & 0.30 & Low \\
\hline
\end{tabular}

MDS - minimum data set, PCA (Wi) - principal component analyses (weighting index), Si - scoring index, $\mathrm{SQI}$ - soil quality index, org $\mathrm{C}$ - organic carbon, exch $\mathrm{Ca}$ - exchangeable calcium, exch $\mathrm{Na}$ - exchangeable natrium

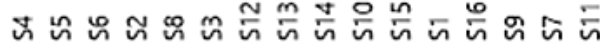

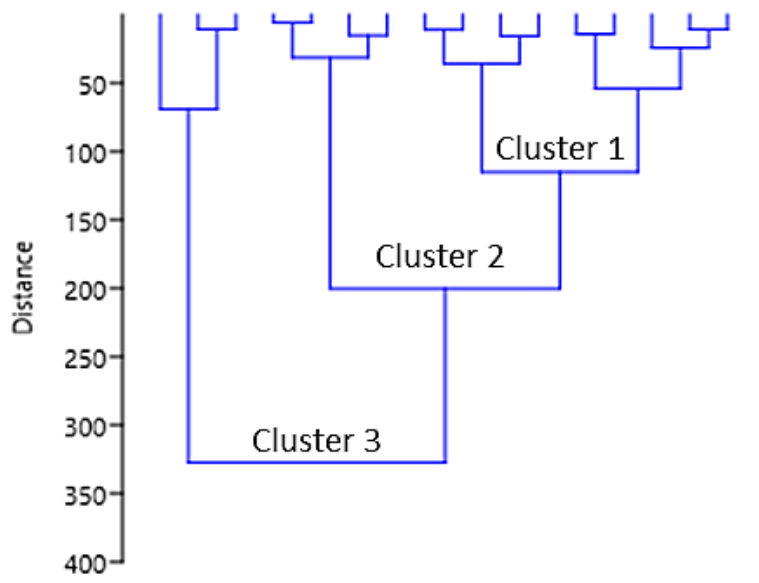

Figure 3. The dendrogram of the cluster analysis

low $\mathrm{pH}$ value (acid) based on soil chemical standard (Indonesian Soil Research Institute, 2005), whereas cluster 2 and cluster 3 have higher $\mathrm{pH}$ value than cluster 1 . The presence of lower $\mathrm{pH}$ value can be related to the decrease of base saturation in the soil. Table 8 shows that cluster 1 has a low base saturation rate compared to other clusters.

In SQI clustering, group of cluster 1 has higher value than cluster 2 and lower than cluster 3 (Table 7). In Table 8, cluster 1 has a high value of $\mathrm{CN}$ ratio and exchangeable $\mathrm{Na}$ while in cluster 2, only exchangeable $\mathrm{Mg}$ had the high value.
The locations of grup cluster 1 was mainly a natural agroforestry system with random cropping pattern (S1, S9, S10, S11, S13, S14, S15, $\mathrm{S} 16)$, except for $\mathrm{S} 7$ with an alley cropping pattern with mixed food crops (Allium fistulosum) and timber (Tectona grandis). Most of the locations in cluster 1 consist of a mixture of timbers (Tectona grandis, Gmelina arborea, Albizia chinensis, Toona sureni Merr), horticultures (Manihot esculenta, Allium fistulosum), multi purpose trees (Mangifera indica L, Musa paradisiaca L, Syzygium aromaticum, Mangifera indica L, Gnetum gnemon, Durio sp, Carica papaya) and grasses (Ageratum conyzoides, Synedrella nudiflora) that result in high $\mathrm{CN}$ ratio content. A higher diversity of tree species result in faster decomposition of organic content (Wang et al., 2014) and enhanced carbon-nitrogen $(\mathrm{CN})$ ratio.

The higher levels of exchangeable magnesium (Table 8 ) in cluster 2 were possibly caused by the clay content in the each soil location. There is a correlation between the magnesium content and the clay content in the soil (Mikkelsen, 2010). Cluster 2 mainly consisted of a mixture of timbers (Gmelina arborea, Albizia chinensis, Toona sureni Merr), multi purpose trees (Persea americana Mill) and food crop (Manihot esculenta) as dominant. 
Table 7. Cluster analysis of the soil location

\begin{tabular}{|l|l|c|c|}
\hline Cluster & \multicolumn{1}{|c|}{ Soil Location } & Sample (\%) & SQI \\
\hline Cluster 1 & S1, S7, S9, S10, S11, S13, S14, S15, S16 & $56 \%$ & 0.46 \\
\hline Cluster 2 & S2, S3, S8, S12 & $25 \%$ & 0.43 \\
\hline Cluster 3 & S4, S5, S6 & $19 \%$ & 0.51 \\
\hline
\end{tabular}

Table 8. Cluster analysis of chemical parameters of different clustered groups

\begin{tabular}{|l|c|c|c|c|c|c|c|c|c|c|c|c|c|}
\hline Cluster & $\mathrm{pH}$ & org C & total N & CN ratio & av P & av K & exch Ca & exch Mg & exch K & exch Na & CEC & BS \\
\hline \multicolumn{10}{|c|}{ Cluster 1} \\
\hline Min & 4.70 & 1.45 & 0.16 & 8.00 & 84.30 & 9.58 & 6.05 & 2.33 & 0.12 & 0.08 & 15.98 & 50.00 \\
\hline Max & 6.30 & 3.26 & 0.33 & 17.00 & 192.10 & 40.80 & 14.97 & 4.49 & 0.81 & 0.79 & 31.08 & 70.00 \\
\hline Mean & 5.46 & 2.40 & 0.23 & 10.78 & 141.67 & 20.04 & 10.01 & 3.22 & 0.42 & 0.42 & 23.05 & 60.22 \\
\hline \multicolumn{10}{|c|}{ Cluster 2} \\
\hline Min & 5.40 & 1.07 & 0.14 & 8.00 & 41.65 & 8.31 & 6.17 & 3.01 & 0.12 & 0.05 & 16.43 & 51.00 \\
\hline Max & 5.80 & 3.04 & 0.26 & 12.00 & 50.33 & 10.70 & 17.99 & 6.72 & 0.86 & 0.50 & 36.29 & 83.00 \\
\hline Mean & 5.60 & 1.99 & 0.20 & 9.75 & 45.80 & 9.39 & 10.82 & 4.09 & 0.33 & 0.27 & 23.34 & 65.25 \\
\hline \multicolumn{10}{|c|}{ Cluster 3 } & & & & \\
\hline Min & 5.60 & 1.80 & 0.19 & 8.00 & 236.70 & 40.30 & 12.63 & 2.52 & 0.94 & 0.29 & 22.58 & 71.00 \\
\hline Max & 5.80 & 3.19 & 0.40 & 10.00 & 324.20 & 52.16 & 15.05 & 2.94 & 1.29 & 0.51 & 26.90 & 78.00 \\
\hline Mean & 5.70 & 2.52 & 0.28 & 9.00 & 268.78 & 46.92 & 13.85 & 2.78 & 1.09 & 0.38 & 24.30 & 74.67 \\
\hline
\end{tabular}

org $\mathrm{C}$ - organic carbon, av $\mathrm{P}$ - available phosphorus, av $\mathrm{K}$ - available potassium, exch $\mathrm{Ca}$ - exchangeable calcium, exch $\mathrm{Mg}$ - exchangeable magnesium, exch $\mathrm{K}$ - exchangeable potassium, exch $\mathrm{Na}$ - exchangeable natrium, CEC - cation exchange capacity, BS - base saturation

Cluster 3 had the highest SQI (Table 7) compared to other clusters. This cluster has a high value of $\mathrm{pH}$, organic $\mathrm{C}$, total $\mathrm{N}$, available $\mathrm{P}$, available $\mathrm{K}$, exchangeable $\mathrm{Ca}$, cation exchange capacity and base saturation (Table 8). The location of S4, S5, S6 in cluster 3 group was artificial agroforestry system with an alley cropping pattern with coffee as the main product. Cluster 3 consists of a mixture of timbers (Gmelina arborea), multi purpose tree (Coffea arabica L, Mangifera indica L, Artocarpus heterophyllus Lam) and horticultures (Brassica rapa L, Solanum lycopersicum). Agroforestrybased coffee with an intercropping system (timber, multi purpose tree and horticulture) provides better soil quality compared to other clusters. This corresponds with the findings high soil carbon stocks in agroforestry-based coffee compared to the arable land (Lal, 2004; Mohammed and Bekele, 2014). The available phosphorus showed the highest value in the cluster with agroforestry-based coffee and corresponds with the research which found that the phosphorus content was higher in the coffee under organic rather than conventional management (Tully et al., 2013). Agroforestry-based coffee is most commonly cultivated to cope with the physiological stress, decreased soil erosion and to generate additional income for the farmer (Pimentel et al., 2011; Tscharntke et al., 2011).
In order to improve the soil quality, soil and vegetation management by conservation farming need to be considered. The selection of crop types considers the suitability of the growing place, types of protection forest trees. The multipurpose tree species that have strong and deep roots, as well as the grasses that are suitable for livestock are preferred.. The arrangement of plant pattern, layout and planting spacing should be taken into consideration.

\section{CONCLUSION}

The results showed that MDS consisted of four soil chemical indicators and represented $83.6 \%$ of the variability of data, i.e., $\mathrm{pH}$, and exchangeable Calcium (exch $\mathrm{Ca}$ ), organic Carbon (org C), and exchangeable Natrium (exch $\mathrm{Na}$ ) respectively. The soil quality index (SQI) under agroforestry pattern was categorized as moderate. The artificial agroforestry-based coffee with an intercropping system (timber, multi purpose tree and horticulture) provides better soil quality.

Conclusively, appropriate land, soil, and vegetation management by conservation farming, adding of organic matter and fertilizers wellorganized are required to improve and maintain better soil quality and productivity. Furthermore, 
there is need to investigate the technologies for mapping of soil quality and to monitor the health/ quality of the soil from time to time.

\section{Acknowledgements}

This research was supported by Saintek-Kemenristekdikti Scholarships Programme and Research Centre for Geotechnology LIPI. The author would like to thank our colleagues from Research Centre for Geotechnology (Eko Yulianto, Fajar Lubis, Hendra Bakti, Dwi Sarah, Ma'ruf Mukti and Ilham Arisbaya) who provided insight and expertise that greatly assisted the research and helped clarify our ideas.

\section{REFERENCES}

1. Acharya A.K. \& Kafle N. 2009. Land degradation issues in Nepal and its managment through agroforestry. The Journal of Agriculture and Environment 10, 115-123.

2. Alzwar M., Akbar N.A., Bachri S. 1992. Geological Map of Garut and Pameungpeuk Sheet, West Java, scale 1:100.000. Bandung.

3. Andrews S., Karlen D., Cambardella C. 2004. The Soil Management Assessment Framework: A Quantitative Soil Quality Evaluation Method. Soil Science Society of America Journal 68, 1945-1962.

4. Aticho A. 2013. Evaluating Organic Carbon Storage Capacity of Forest Soil : Case Study in Kafa Zone Bita District, Southwestern Ethiopia. American Eurasian Journal of Agriculture and Environmental Science 13, 95-100.

5. Bi C.J., Chen Z.L., Wang J., Zhou D. 2013. Quantitative Assessment of Soil Health Under Different Planting Patterns and Soil Types. Pedosphere 23, 194-204.

6. Brejda J.J., Moorman T.B., Karlen D.L., Dao T.H. 2000. Identification of regional soil quality factors and indicators I. Central and Southern High Plains. Soil Science Society of America Journal 64, 2115-2124.

7. Bremner J.M., Sparks D.L., Page A.L., Helmke P.A., Loeppert R.H., Soltanpour P.N., Tabatabai M.A., Johnston C.T., Sumner M.E. 1996. Nitrogen-total. Methods of soil analysis. Part 3-Chemical methods. 1085-1121.

8. Cantú M.P., Becker A., Bedano J.C., Schiavo H.F. 2007. Soil quality evaluation using indicators and indices. Ciencia del Suelo 25, 173-178.

9. Chaidar A.N., Soekarno I., Wiyono A., Nugroho J. 2017. Spatial analysis of erosion and land criticality of the upstream citarum watershed. International Journal of GEOMATE 13, 133-140.
10. Combe J. \& Budowski G. 1979. Classification of agro-forestry techniques. In: de las Salas G. (Ed.). Proceedings of the Workshop on Agroforestry Systems in Latin America CATIE. Turialba, Costa Rica, 17-47.

11. De Foresta H. \& Michon G. 1996. The agroforest alternative to Imperata grasslands: when smallholder agriculture and forestry reach sustainability. Agroforestry Systems 36, 105-120.

12. Doran J.W. \& Parkin T.B. 1994. Defining and assessing soil quality. In: Doran, J.W.,Coleman, D.C., Bezdicek, D.F., Stewart, B.A. (Eds.), Defining Soil Quality for aSustainable Environment. SSSA Spec. Publ. 35. ASA, Madison, WI, 3-21.

13. Emadi M., Baghernejad M., Memarian H.R. 2009. Effect of land-use change on soil fertility characteristics within water-stable aggregates of two cultivated soils in northern Iran. Land Use Policy 26, 452-457.

14. Govaerts B., Sayre K.D., Deckers J. 2006. A minimum data set for soil quality assessment of wheat and maize cropping in the highlands of Mexico. Soil and Tillage Research 87, 163-174.

15. Hairiah K., Sulistyani H., Suprayogo D., Purnomosidhi P., Widodo R.H., Van Noordwijk M. 2006. Litter layer residence time in forest and coffee agroforestry systems in Sumberjaya, West Lampung. Forest Ecology and Management 224, 45-57.

16. Hammer Ø., Harper D.A.T., Ryan P.D. 2001. PAST: Paleontological statistics sofware package for education and data analysis. Palaeontologia Electronica 4, 1-9.

17. Hesse P.R. 1971. A textbook of soil chemical analysis, first ed. Chemical Publishing Co., New York.

18. Indonesian Soil Research Institute. 2005. Soil Chemical, Crop, Water and Fertilizer Analysis. Soil Research Institute, Research Agency and Agricultural Development, Ministry of Agriculture, Jakarta.

19. Jin Z., Li Z., Li Q., Hu Q., Yang R., Tang H., Li M., Huang B., Zhang J., Li G. 2015. Canonical correspondence analysis of soil heavy metal pollution, microflora and enzyme activities in the $\mathrm{Pb}-\mathrm{Zn}$ mine tailing dam collapse area of Sidi village, SW China. Environmental Earth Sciences 73, 267-274.

20. Karlen D.L., Ditzler C., Andrews S.S. 2003. Soil quality: Why and how? Geoderma 114, 145-156.

21. Karlen D.L., Gardner J.C., Rosek M.J. 1998. A soil quality framework for evaluating the impact of CRP. Journal of Production Agriculture 11, 56-60.

22. Kassa H., Dondeyne S., Poesen J., Frankl A., Nyssen, J. 2017. Impact of deforestation on soil fertility, soil carbon and nitrogen stocks: the case of the Gacheb catchment in the White Nile Basin, Ethiopia. Agriculture, Ecosystems \& Environment 247, 273-282.

23. King K.F.S. 1979. Agroforestry and the utilisation of fragile ecosystems. Forest Ecology and Management 2, 161-168.

24. King K.F.S. 1976. Agri-silviculture (the taungya 
system). University of Ibadan, Ibadan (Nigeria). Department of Forestry.

25. Laishram J., Saxena K.G.G., Maikhuri R.K.K. \& Rao, K.S.S. 2012. Soil Quality and Soil Health : A Review. International Journal of Ecology and Environmental Sciences 38, 19-37.

26. Lal R. 2004. Soil carbon sequestration impacts on global climate change and food security. Science 304, 1623-1627.

27. Larson W.E. \& Pierce F.J. 1994. The dynamics of soil quality as a measurement of sustainable management. Defining soil quality for a sustainable environment 551, 37-51.

28. León J.D. \& Osorio N.W. 2014. Role of litter turnover in soil quality in tropical degraded lands of Colombia. The Scientific World Journal 2014. article ID: 693981. Hindawi Publishing Corporation

29. Li P., Zhang T., Wang X. \& Yu D. 2013. Development of biological soil quality indicator system for subtropical China. Soil and Tillage Research 126, 112-118.

30. Marinho E.B., de Oliveira A.L., Zandonadi D.B., Benedito L.E.C., de Souza R.B., de Figueiredo C.C. \& Busato J.G. 2014. Organic matter pools and nutrient cycling in different coffee production systems in the Brazilian Cerrado. Agroforestry systems 88, 767-778.

31. Michon G. \& de Foresta H. 1999. Agro-forests: incorporating a forest vision in agroforestry, in: Buck, L.E., J.P.L. and E.C.M.F. (Ed.), Agroforestry in Sustainable Agricultural Systems. CRC Press, Lewis Publishers, pp. 381-406.

32. Mikkelsen R. 2010. Soil and fertilizer magnesium. Better crops 94, 26-28.

33. Ministry of Agriculture. 2015 Integrated Land Conservation Development Management Support. Land Expansion Directorate. Indonesia Ministry of Agriculture.

34. Mohammed A. \& Bekele L. 2014. Changes in Carbon Stocks and Sequestration Potential under Native Forest and Adjacent Land use Systems at Gera, SouthWestern Ethiopia. Global Journal of Science Frontier Research: D Agriculture and Veterinary 14, 11-19.

35. Nair P.K.R. 1998. Directions in tropical agroforestry research: past, present, and future, in: Directions in Tropical Agroforestry Research. Springer, 223-245.

36. Olsen S.R. 1954. Estimation of available phosphorus in soils by extraction with sodium bicarbonate. United States Department Of Agriculture; Washington.

37. Parikesit, Takeuchi K., Tsunekawa A., Abdoellah O.S. 2005. Kebon tatangkalan: A disappearing agroforest in the Upper Citarum Watershed, West Java, Indonesia. Agroforestry Systems 63, 171-182.

38. Pimentel, M.S., De-Polli, H., Aquino, A.M. de, Correia, M.E.F., Rouws, J.R.C. 2011. Bioindicators of soil quality in coffee organic cultivation systems. Pesquisa Agropecuaria Brasileira 46, 545-552.

39. Qi Y., Darilek J.L., Huang B., Zhao Y., Sun W., Gu Z. 2009. Evaluating soil quality indices in an agricultural region of Jiangsu Province, China. Geoderma 149, 325-334.

40. Raiesi F. \& Beheshti A. 2014. Soil C turnover, microbial biomass and respiration, and enzymatic activities following rangeland conversion to wheat--alfalfa cropping in a semi-arid climate. Environmental Earth Sciences 72, 5073-5088.

41. Saviozzi A., Levi-Minzi R., Cardelli R., Riffaldi R. 2001. A comparison of soil quality in adjacent cultivated, forest and native grassland soils. Plant and Soil 233, 251-259.

42. Shukla M.K., Lal R., Ebinger M. 2006. Determining soil quality indicators by factor analysis. Soil and Tillage Research 87, 194-204.

43. Silitonga P.H. 1973. Geological Map of Bandung Sheet, West Java, Scale 1:100.000. Bandung.

44. Soil and Agroclimate Research Center. 1993. Soil Map of Citarum Watershed, West Java, Scale 1:100.000. Bogor.

45. Soil Survey Staff. 2014. Keys to Soil Taxonomy. 12th edition, USDA. Soil Conservation Service.

46. Spohn M. \& Giani L. 2011. Impacts of land use change on soil aggregation and aggregate stabilizing compounds as dependent on time. Soil Biology and Biochemistry 43, 1081-1088.

47. Supriyadi S., Purwanto P., Sarijan A., Mekiuw Y., Ustiatik R., Prahesti R.R. 2017. The assessment of soil quality at paddy fields in Merauke, Indonesia. Bulgarian Journal of Agricultural Science 23, 443-448.

48. Tscharntke T., Clough, Y., Bhagwat S.A., Buchori D., Faust H., Hertel D., Hölscher D., Juhrbandt J., Kessler M., Perfecto I. 2011. Multifunctional shadetree management in tropical agroforestry landscapes - a review. Journal of Applied Ecology 48, 619-629.

49. Tully K.L., Lawrence D., Wood S.A. 2013. Organically managed coffee agroforests have larger soil phosphorus but smaller soil nitrogen pools than conventionally managed agroforests. Biogeochemistry $115,385-397$.

50. Walky A. \& Black I.A. 1934. An examination of Degtjareff method for determining soil organic matter and proposed modification of the Chromic acid titration method. Journal Soil Science 37, 29-38.

51. Wang Y., Chang S.X., Fang S., Tian, Y. 2014. Contrasting decomposition rates and nutrient release patterns in mixed vs singular species litter in agroforestry systems. Journal of Soils and Sediments 14, 1071-1081.

52. Young A. 1989. Agroforestry for soil conservation. Science and Practice of Agroforestry No. 4, ICRAFT, Nairobi. 